IwONA ChMURA-RutKOWSKA

ORCID 0000-0002-9319-7767

EDYTA GŁOWACKA-SOBIECH

ORCID 0000-0003-3958-3859

IZABELA SKÓRZYŃSKA

ORCID 0000-0002-2549-8592

Uniwersytet im. Adama Mickiewicza

$w$ Poznaniu

\title{
UNWORTHY OF HISTORY? \\ ON THE ABSENCE AND STEREOTYPICAL IMAGES OF WOMEN SCIENTISTS IN LIGHT OF THE HISTORICAL NARRATIVE IN MIDDLE AND SECONDARY SCHOOL TEXTBOOKS
}

\begin{abstract}
AвSTRACT. Chmura-Rutkowska Iwona, Głowacka-Sobiech Edyta, Skórzyńska Izabela, Unworthy of History? On the Absence and Stereotypical Images of Women Scientists in Light of the Historical Narrative in Middle and Secondary School Textbooks [Niegodne miejsca w historii? O nieobecności i stereotypowych wizerunkach kobiet naukowców w świetle narracji historycznej w podręcznikach do szkół średnich i gimnazjów]. Studia Edukacyjne nr 53, 2019, Poznań 2019, pp.117-142. Adam Mickiewicz University Press. ISSN 1233-6688. DOI: 10.14746/ se.2019.53.8
\end{abstract}

Our research project "Unworthy of History" focuses on discussing the historical narrative in Polish history textbooks that are used in teaching history at the middle school level. The aim is to analyze and describe ways of thinking about as well as presenting the role and place of women and men in history in schools.

Research shows that women are portrayed in textbooks as playing a less important role than men they are almost non-existent in public life. "(...) what is male is universal. What is female is accidental and secondary". The few women that are mentioned in these textbooks are portrayed in traditional roles, usually family roles, and in those contexts and spheres of life that are culturally considered to be typically feminine. Women are not only under-represented in history textbooks; also, information about them is often distorted or simply untrue. The topic of the (in)equality between women and men as well as the history of women's emancipation movements, which are related to the empowerment of half of humanity, is not considered worthy to be presented in Polish textbooks.

Our presentation and study focused on the absence and stereotypical representations of women scientists in Polish history textbooks. The results reveal that although women could be as creative and hard working as men - not exclusively in the fields traditionally associated with women (e.g. Josephine 
Cochran invented the dishwasher in 1872, and Marion Donovan - disposable diapers in 1950) but also in those associated with men (e.g. Mary Anderson created windshield wipers in 1903 and Grace Murray found the first computer bug in 1947) - their contribution to the development of societies is marginalised, trivialised or totally omitted by the authors Polish history textbooks. In every textbook analysed, men make up over $90 \%$ of characters introduced by name although they were not necessarily widely known. On the other hand, women who achieved professional success in science, art or social development get ignored.

Key words: history, herstory, women scientists, historical narrative

\section{Why it is So Important for Girls to Find Women-Scientist Role Models in Textbooks?}

Since the idea and practice of coeducation has become popular, public education has been dominated by the belief that the school as institution is "gender-neutral". Sexism, meanwhile, has become, to a large extent, an element of the "hidden program" of the school, and therefore completely invisible and undetected for most of its participants. ${ }^{1}$ One of the examples of this is the absence of biographies and the histories of the achievements of women scientists. It is highly probable that a young man completing a long-term obligatory course in history in a Polish school will know only the name of one woman who has been successful in science. This builds an excellent foundation for the belief that women have had no influence on the development of knowledge and that all the significant and world-changing scientific discoveries were made exclusively by men. However, there are numerous examples of women's talents, genius and diligence (as well as examples of their destruction due to misogyny) throughout the history of mankind. ${ }^{2}$ The negative consequences of the absence of women scholars in the school historical narrative are confirmed, among others, by the study entitled: "Beautiful minds. The role of women in the world of science". ${ }^{3}$ In selecting the greatest exponents of science, as many as $71 \%$ of the 1012 respondents participating in the Polish study, identified men, and only $33 \%$ of the respondents chose women. Among the most prominent scientists Maria Skłodowska-Curie ranked second with a score of $27 \%$ and was the only woman in that distinguished group. Only

${ }^{1}$ R. Meighan, Socjologia edukacji, Toruń 1993; M. Karkowska, Socjalizacja rodzajowa dziewcząt i chtopców a ukryty program edukacji szkolnej, [in:] Role płciowe. Kultura i edukacja, Ed. M. Chomczyńska-Rubacha, Łódź 2006; L. Kopciewicz, Rodzaj i edukacja. Studium fenomenograficzne z zastosowaniem teorii społecznej Pierre'a Bourdieu, Wrocław 2007.

${ }^{2}$ R. Swaby, Upór i przekora. 52 kobiety, które odmienity naukę i świat, Warszawa 2017.

${ }^{3}$ A. Fandrejewska-Tomczyk, Raport L'Oréal Polska, Piękne umysty - rola kobiet w świecie nauki, Warszawa 2016. http://lorealdlakobietinauki.pl/wp-content/uploads/2016/05/16-04-26_ Raport_Piekne_umysly-rola_kobiet_w_swiecie_nauki.pdf. [01.02.2019]. 
Albert Einstein was ahead of her. This proportion not only corresponds to Skłodowska-Curie's position in the textbook narratives, but also testifies to the social conviction (memory) of the uniqueness of the Polish scientist working in France. The thing is that both in textbooks and in public opinion, she is the only representative of female scientists, this results not only from her achievements, but also from the widespread belief that a female scientist is a representative of science or natural science. Which means that a humanist is not to be considered a scientist, let alone a woman who deals scientifically with art or literature. This tendency is confirmed by the results of the research quoted and the highest indications concerning the scientific activity of women in such areas as culture and art, social issues or foreign languages. Moreover, the selected achievements of women in science and medicine (for example, concerning the discovery that the composition of the stars is $98 \%$ helium and hydrogen, or the discovery that the HIV virus causes AIDS) were attributed to men by the vast majority of respondents. ${ }^{4}$

Meanwhile, research into the education of girls and their later life choices and careers show clearly that the number of girls who are interested in science doubles when they have an inspirational role model. ${ }^{5}$ This effect is particularly evident in science, technology, engineering, and mathematics (STEM) that are still considered "typically male" subjects. ${ }^{6}$ Fascinating and unusual characters, both currently active researchers and scientists, as well as heroines from the past can effectively support the talents and development of modern girls.

The curricula of history lessons (at all levels of education) resulting from the recent changes in Polish education, carried out by Minister Anna Zalewska, do not raise any hopes and do not contribute to the promotion of women-scientists from the past. This is not an isolated opinion. ${ }^{7}$ Anna Dzierzgowska

${ }^{4}$ Ibidem.

${ }^{5}$ Microsoft, How role models are changing the face of STEM in Europe, 2017. https://news. microsoft.com/europe/features/girls-in-stem-the-importance-of-role-models/. [01.02.2019].

${ }^{6}$ UNESCO, Girls into Science: A training Module, Paris 2007; file:///C:/Users/Krystyna/ Desktop/Iwona/Girls\%20into\%20Science\%20UNESCO.pdf; UNESCO, Cracking the code: Girls' and women's education in science, technology, engineering and mathematics, Paris 2017. http:// unesdoc.unesco.org/images/0025/002534/253479e.pdf. [01.02.2019]; European Commission, SHE FIGURES 2015, Gender in Research and Innovation. Brussels 2015. https:/ / ec.europa.eu/research/swafs/pdf/pub_gender_equality/she_figures_2015-final.pdf; [01.02.2019]; C. Hill, Ch. Corbett, A.S. Rose, Why So Few? Women in Science, Technology, Engineering, and Mathematics, Washington 2010. https://www.aauw.org/files/2013/02/Why-So-Few-Women-in-Science-Technology-Engineering-and-Mathematics.pdf. [01.02.2019]; L. Kekelis, J. Joyce, How Role Models Can Make the Difference for Girls, The Journal of Expanded Learning, Spring 2014.

7 A. Dzierzgowska, P. Laskowski, Opinia zespotu Społecznego Monitora Edukacji o projekcie podstawy programowej z historii dla liceum ogólnoksztatcącego i technikum. Warszawa 2017. https:/ / www.monitor.edu.pl/analizy/opinia-o-projekcie-podstawy-programowej-z-historii-dla-liceum-ogolnoksztalcacego-i-technikum.html [01.02.2019]. 
and Piotr Laskowski in 2017 analyzed the proposed history curriculum for upper secondary general and technical schools. Although their analysis concerns the draft version of the history curriculum for upper secondary general and technical schools, the comments of the Authors' from the Social Education Monitor can be upheld today.

At all stages of historical education, history is/will be repeated throughout the entire learning cycle by all students (with the exception of vocational schools, where history is taught at the first level covering only the period after World War I, while at the second cycle there is no history course at all). Knowledge conveyed at all levels has been highly detailed, as well as the skills required (not specified precisely and too vaguely presented by the legislator but nevertheless numerous); there is not enough emphasis put on students' attitudes. ${ }^{8}$

The role and purpose of historical education is to develop the skills of critical thinking about the past, and at the same time to undertake the task of building identity. Hence, it should be expected that the contemporary teaching of history can and even should play the role of emancipatory, equality education, open to diversity and tolerance. Are these values taken into consideration when constructing successive curricula and textbooks? Can we be sure that after taking the history course in Polish schools, young Polish women and young Poles will be reflective and free from stereotypical clichés in the perception of people and in their behaviour both in the past and in today's world? Do the Polish curricula take into account the diversity and gender order of the past?

Our research into lower secondary school textbooks conducted before the education reform of A. Zalewska, as well as the analysis of new curricula regarding history teaching prove that the above mentioned diversity and gender sensitivity is missing. Polish historical education together with new guidelines returns to the 19th century paradigm and methods of history teaching, based mainly on memorization.

In the opinion of the aforementioned authors, A. Dzierzgowska and P. Laskowski,

these goals and the curriculum developed in order to achieve them do not meet the educational requirements stated in international law documents; in particular, they

\footnotetext{
${ }^{8}$ MEN, Podstawa programowa kształcenia ogólnego dla szkoły podstawowej. https:/ / podstawaprogramowa.pl/Szkola-podstawowa-IV-VIII/Historia [05.08.2018]. Rozporządzenie Ministra Edukacji Narodowej z 14 lutego 2017 r. w sprawie podstawy programowej wychowania przedszkolnego oraz podstawy programowej kształcenia ogólnego dla szkoły podstawowej, $\mathrm{w}$ tym dla uczniów z niepełnosprawnością intelektualną w stopniu umiarkowanym lub znacznym, kształcenia ogólnego dla branżowej szkoły I stopnia, kształcenia ogólnego dla szkoły specjalnej przysposabiającej do pracy oraz kształcenia ogólnego dla szkoły policealnej (DzU z 2017 r., poz. 356).
} 
are in conflict with art. 28. $1 \mathrm{~d}$ of the Convention on the Rights of the Child, which states that a child's education should be directed towards preparation for a proper life in a free society, in a spirit of understanding, peace, tolerance, gender equality and friendship between all nations, ethnic groups, national and religious and indigenous people. ${ }^{9}$

Moreover, as rightly pointed out by A. Dzierzgowska and P. Laskowski,

this is a history described primarily from a political and military perspective, in which the apparent subject is "the nation" and "the state", and the real one is the narrow elite, a polonocentrically and europocentrically oriented history, and finally - a history constructed in a way that almost completely neglects everything that is happening in historical sciences at least from the middle of the nineteenth century. ${ }^{10}$

And indeed, all the achievements in the field of social history, the history of thought or everyday life have basically been completely omitted.

In relation to the previous core curriculum (for lower secondary school), similar accusations can be made: political history prevailed in it, there were no specific female historical figures (the Causative Agents are both the Middle East and Montesquieu, but never a woman). It was very general, which could have, but has not been used to its advantage, because the textbooks analyzed by us lacked openness, for example, to the role of women in history. ${ }^{11}$ The new curriculum, on the other hand, repeats all the faults of its predecessor: the historical figures which appear are mainly men, in their roles as politicians and military leaders. The military perspective dominates historical events, especially in relation to the so-called "cursed soldiers" (Pol. Żotnierze Wyklecci). There is also an over-representation of topics concerning the role of the Catholic church in the history of Poland, as well as the strong presence of Messianic and martyrological interpretations of history. ${ }^{12}$ Such a historical narrative is not conducive to a critical view of the past. And it makes history a subject that is not particularly liked by students.

\footnotetext{
${ }^{9}$ A. Dzierzgowska, P. Laskowski, Opinia zespotu Społecznego Monitora Edukacji.

${ }^{10}$ Ibidem.

${ }^{11}$ See: I. Chmura-Rutkowska, E. Głowacka-Sobiech, I. Skórzyńska, Niegodne historii? O nieobecności i stereotypowych wizerunkach kobiet w świetle podręcznikowej narracji historycznej w gimnazjum, Poznań 2015, p. 79-86.

${ }^{12}$ MEN, Podstawa programowa kształcenia ogólnego dla szkoły podstawowej. https:/ / podstawaprogramowa.pl/Szkola-podstawowa-IV-VIII/ [30.11.2019]; Rozporządzenie Ministra Edukacji Narodowej z 14 lutego 2017 r. w sprawie podstawy programowej wychowania przedszkolnego oraz podstawy programowej kształcenia ogólnego dla szkoły podstawowej, w tym dla uczniów z niepełnosprawnością intelektualną w stopniu umiarkowanym lub znacznym, kształcenia ogólnego dla branżowej szkoły I stopnia, kształcenia ogólnego dla szkoły specjalnej przysposabiającej do pracy oraz kształcenia ogólnego dla szkoły policealnej (DzU z 2017 r.), poz. 365. http://dziennikustaw.gov.pl/du/2017/365/1 [30.11.2019].
} 
The new core curriculum is full of clichés and patriotic "gibberish". Its authors write that its purpose is

Getting to know important events from the history of the Polish nation, especially through the achievements of outstanding historical figures; familiarization with national, state and religious symbols; explaining their meaning and shaping respect towards them is the role of history. It is during the history course when the feeling of love for the homeland through respect and attachment to the tradition and history of one's own nation and its achievements, culture and mother tongue is shaped. It is equally important to form a bond with the home country, civic awareness, an attitude of respect and responsibility for their own state, and a sense of dignity and national pride. $^{13}$

\section{And further it follows that:}

Collective memory preserves the image of history. Our native memory has been forming for over a thousand years. The one that covers common history counts for millennia. The school should ensure that the student does not get lost in the multitude of details, but learns the most important of them, he should be able to explain the rules governing the past: political, social, economic, religious and cultural. Such an approach to explaining history is intended to help students understand the mechanisms of the present. It is also important for students in adulthood to consciously and responsibly co-create a European community of values with the superior, especially close to us, Poles, idea of freedom. Freedom, which in the last centuries was expressed in the quest to regain independence and maintain state sovereignty (...). In primary schools, the student first gets to know national history. In the core curriculum for secondary schools, the history of the state and the nation has been more deeply inscribed in general history, although still, of course, the thread of national history remains the most important. ${ }^{14}$

Young people and children identify themselves fully with school knowledge when they see a place for themselves in it: now as adults, in a united Europe. The goals of education found in the curriculum are not reflected in the prescribed teaching content. For example, there are hardly any women, especially scientists, represented in the curriculum.

Both curricula ignore the role of women in history. The new curriculum lists the following women: Dobrawa, Jadwiga, M. Skłodowska-Curie and D. Siedzikówna ("Inka") - in elementary schools, and I. Sendlerowa,

\section{${ }^{13}$ Ibidem.}

${ }^{14}$ MEN, Podstawa programowa kształcenia ogólnego dla czteroletniego liceum ogólnokształcącego i pięcioletniego technikum. https://podstawaprogramowa.pl/Liceum-technikum/Historia [30.11.2019]; Rozporządzenie Ministra Edukacji Narodowej z 30 stycznia 2018 r. w sprawie podstawy programowej kształcenia ogólnego dla liceum ogólnokształcącego, technikum oraz branżowej szkoły II stopnia. (DzU z 2018 r. poz. 467). http:/ / www.dziennikustaw. gov.pl/DU/2018/467 [30.11.2019]. 
A. Żabińska - in upper-secondary general and technical schools. There are no women present in the curriculum for the first cycle of vocational schools.

What is the representation of women, especially of scholars, in the new curricula for the history teaching? Clearly, it can be said that only unconventional and outstanding female figures pass through the fine sieve. The only female researcher is Maria Skłodowska-Curie; however she appears only at the level of primary education, which by definition is planned as learning primarily about national history. It was similarly organized in the previous curriculum.

It is worth noting that male scientists, researchers, philosophers, artists and writers - appear in the new core curriculum, so the Authors of the curriculum took note of this side of human activity in the past (P. Skarga, St. Konarski, St. Leszczyński, St. Staszic, H. Kołłątaj, KK Baczyński, T. Gajcy Z. Rumel - in the extended program for upper secondary general and technical education, John Paul II -for the same level of education and primary education, M. Copernicus, John Paul II, L. da Vinci, M. Anioł, R Santi, Erazm from Rotterdam, Montesquieu, JJ Rousseau, M. Rej, J. Kochanowski, St. Konarski, St. Leszczyński, AF Modrzewski, J. Gutenberg, M. Luter, J. Kalwin - primary education).

Silencing many unusual female characters, as well as types of women's activity (for example in science), deprecating their values and work, trivializing their role in history, emphasizing their subordination to men, over-interpretations and patriarchal fantasies, unwarranted attribution of stereotypical traits - these are just some of the many school practices that transform an inspirational heroine from the past into a flat, uninteresting and unreal figure or a dehumanized saint. Perhaps there is a chance that female characters, although omitted by the authors of the core curriculum, will be identified by textbook authors. Perhaps, in the end, an equality sign could be placed between females and males in Polish history education, the recognition of both genders as Causative Agents in history.

Presenting the results of our research, we demand recognition for inspiring, gifted women who change the world for the better. We do it, being aware that it is not enough, as Monika Bobako writes, to compensate for the absence of women in the historical narrative ("compensatory historiography"), for example to supplement it with "lost chapters about the forgotten half of humanity" ${ }^{15}$ but one also has to change the way of presenting the history, not from only one, but from many points of view. In the postulate of taking into account the history of women in textbooks, it is not only about the emancipation of their / our history, but about the emancipation of all of us. Not only

${ }^{15}$ M. Bobako, Powrót kobiet do historii - niedokończony projekt? Krytyka Polityczna, 2005, 7-8. 
about knowledge about "how it was", but also about the art of living "here and now". As is noted by Rita Felski: history is not only a "philosophical problem" but also "an urgent social and pragmatic problem. For many individuals and groups, it is decisive when it comes to the sense of their own human and social subjectivity". ${ }^{16}$

\section{Own Research}

The research project "Unworthy of History" (2010-2014) focuses on discussing the historical narrative in textbooks used in middle schools in Poland to teach history. The project's aim was to analyse and describe both ways of thinking as well as presenting in schools the role and place of men and women in history. Another project, which we conducted between 2013 and 2015, focuses on numerous gender categories in Polish textbooks, including the qualitative analysis of the place and role of women in contemporary history, as depicted in school historical narrative, using textbooks intended for Year One of secondary school. Because, in accordance with the current curriculum, history textbooks used in middle school only cover the history of men from prehistory until 1918, in our presentation we have also taken into account data generated by researching history textbooks used in Year One of secondary school. In total nine sets of textbooks for middle school (Years One to Three) and eight textbooks for Year One of secondary school have been analysed (all of them approved for classroom use in the school years 2010-2012) ${ }^{17}$. Averaging the result, in the analysed textbooks the ratio of representation of women as compared to men is 1:9. How then, in this context, does the history of women in science present itself? That representation is so meagre that it was possible for us to present all the women who, in light of school textbook narrative, were more or less associated with science; those who conducted research and achieved success as well as those who were depicted as intelligent, wise and religious women, organisers and patronesses of science and arts. Finally, also those who we know were scientists but found their way into textbooks for reasons other than their scientific career.

${ }^{16}$ R. Felski, Fin de siecle, fin de sexe: transeksualizm i śmierć historii, [in:] Pamięć, etyka i historia. Anglo-amerykańska teoria historiografii lat dziewięćdziesiątych (Antologia przekładów), Ed. E. Domańska, Poznań 2002, p. 299.

17 See: E. Głowacka-Sobiech et al., Historia - raport przedmiotowy, [in:] Gender w podręcznikach. Projekt badawczy. Raport, t. III - Raporty przedmiotowe i rekomendacje, Eds. I. Chmura-Rutkowska, M. Duda, M. Mazurek, A. Sołtysiak-Łuczak, Warszawa 2016, p. 7-40. 


\section{The Genealogy of Scholarly Women... (from Antiquity to the Modern Age)}

Regarding Antiquity, women are portrayed mostly with a reference to the magical powers of selected goddesses and priestesses. In case of the latter we can talk about their possible links to proto-science. However, as the school textbooks do not have a systematic lecture on the history of science, there is also no reason to believe that students are reflecting on the category of science for both women and men. Another strategy (only in individual cases) of portraying ancient women and their connections to science is assigning to some of them the attributes of wisdom (the Greek goddess Athena) and/or superior intelligence (hetairas [Latin: hetaerae] and Aspasia).

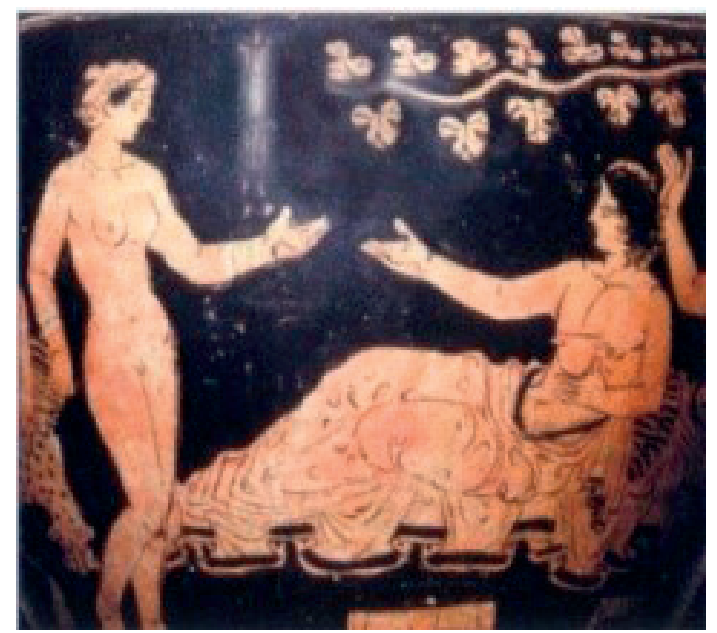

Fig. 1. „During the feasts together with the men sat company ladies called hetairai. They had to be not only beautiful, but also intelligent, to be able to entertain men with conversation" 18

"Aspasia, a life companion of Pericles, famous for her beauty and intelligence, was not a citizen of Athens, she came from Miletus"19

In the Middle Ages, the attributes of female scholarship are wisdom and religiousness. Against this background stand out duchesses, queens and religious women, but (with one exception) we won't learn about any intellectual legacy left by them. All textbooks mention Matilda of Tuscany's qualities as a negotiator between Holy Roman Emperor Henry IV and Pope

${ }^{18}$ J. Ustrzycki, Historia 1. Podręcznik dla gimnazjum, Gdynia 2009, p. 53.

${ }_{19}$ Ibidem, p. 56. 
Gregory VII; recurring is also a miniature depicting Matilda of Germany, accompanied by a succinct caption about her giving the manuscript (liturgical codex) to Mieszko II.

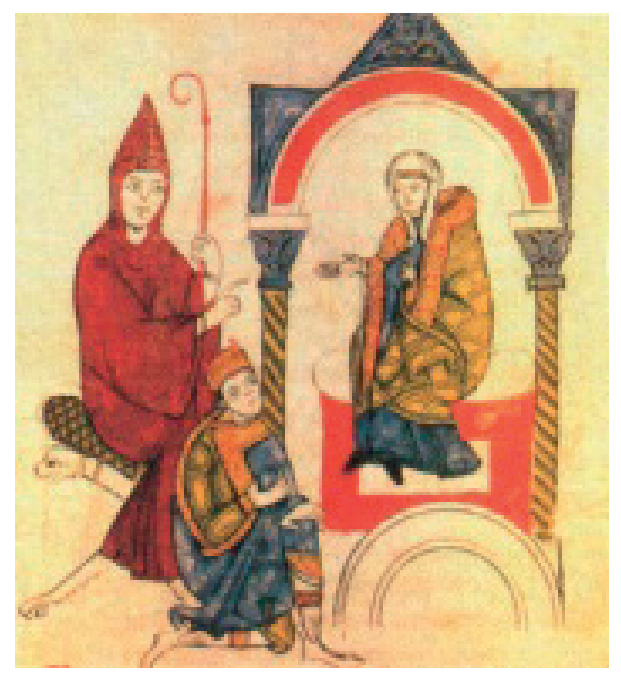

Fig. 2. „Henry IV asks Matilda, the lady of the castle in Canossa and Hugo, the abbot of the Benedictine monastery at Monte Casino, for intercession with Pope Gregory VII. Miniature $\left(12^{\text {th }} \text { century }\right)^{\prime 20}$

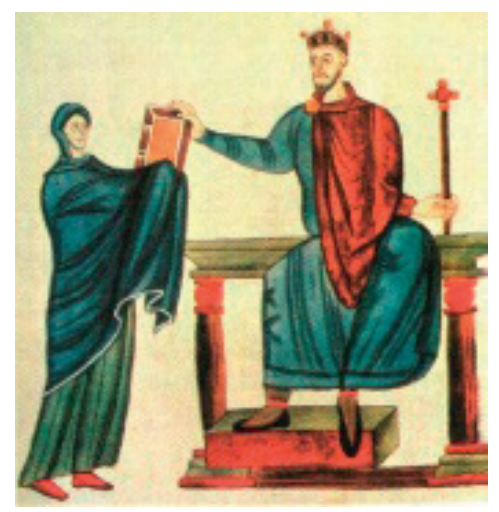

Fig. 3. „Mieszko II receives a liturgical book, helpful in celebrating the Holy Mass from Matilda of Germany, Countess Palatine of Lotharingia. On a miniature from the $12^{\text {th }}$ century Mieszko was shown in his royal majesty, in a diadem and with a scepter in his hand"21

${ }^{20}$ L. Trzcionkowski, L. Wojciechowski, Historia. Starożytność, średniowiecze. Podręcznik dla gimnazjum. Klasa I, Warszawa 2009, p. 100.

${ }^{21}$ Ibidem, p. 115. 
This group of women also includes Dobrawa of Bohemia and Jadwiga of Anjou, the latter characterised by her exceptional education and commitment to the restoration of the Krakow Academy.

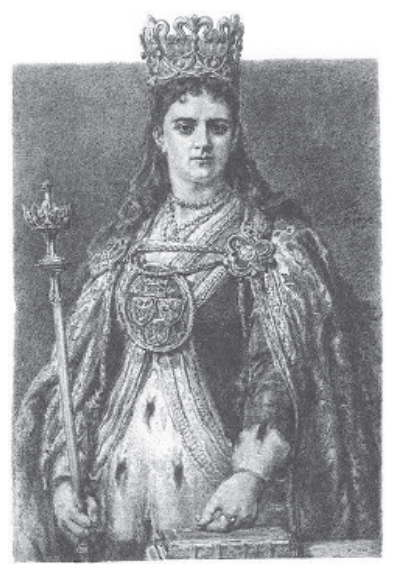

Fig. 4. „Queen Jadwiga Andewageńska, the first wife of Władysław Jagiełło (portrait by Jan Matejko). The queen aroused admiration of modern people with wisdom, kindness, devotion, accessibility and other features" 22

For Jadwiga, a consent to her marriage with Jagiełło was an act of a great personal sacrifice for the adopted country. A young, beautiful girl was raised in the excellent cultural environment of the Anjou court in Buda. She could read and write, knew five languages fluently, had a large library, was an expert in literature and science, music and art, and married an illiterate Lithuanian! (...) Before her death, she devoted her robes and jewels to the renewal of the Krakow Academy ${ }^{23}$.

In one textbook Eleanor of Aquitaine is cast in the role of a broad-minded woman, a patron of the artists: an

influential and well educated queen of France and England, who read Latin, enjoyed literary works, with an excellent knowledge about politics; who cared about the advancement of music and poetry. ${ }^{24}$

${ }^{22}$ Ibidem, p. 160.

${ }^{23}$ R. Kulesza, S. Ciara, Klasa 1. W kalejdoskopie dziejów. Podręcznik do historii, Warszawa 2009, p. 237.

${ }^{24}$ S. Roszak, Śladami przeszłości. Podręcznik do historii dla klasy drugiej gimnazjum, Warszawa 2010, p. 76. 


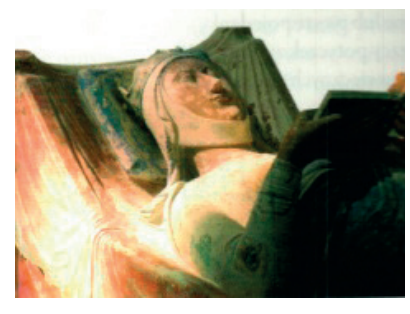

Fig. 5. „Eleanor of Aquitaine (around 1122-1204) was the patron of many well-known medieval poets. That is why a statue of a queen reading a book is placed on her tomb ${ }^{\prime 25}$.

Also, only in that particular textbook, we find mention of Anna Komnene and her "Alexiad" (legacy):

In the Christian East, thinkers created their outstanding works, among them the theologian, St. Maximus the Confessor and Anna Comnena - a daughter of the Byzantine emperor, the author of the excellent historical work, the Alexiad. ${ }^{26}$

In two textbooks we can find an allegory of the Seven Liberal Arts, but only one of them mentions Herrada as its authoress (There is no mention however that Herrada of Landsberg was an authoress of "Hortus Deliciarum", written for novices).

The modern era, similarly to antiquity and the Middle Ages, also belonged to men according to school textbook narratives. The lack of mentions of the role of women in history is all the more noticeable, because the textbook authors devote a lot of space to the cult of science emerging in Europe at the time, as well as the emergence and development of new fields of sicence. In this context women are rarely presented as self-functioning, well-educated and outstanding rulers,

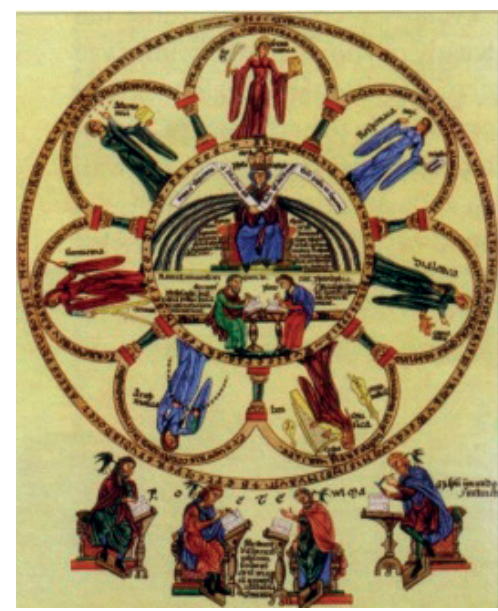

Fig. 6. "Alegory of the seven liberal arts by Herrad of Landsberg (around 1180)" 27 patrons and organizers of the scientific and artistic life of Europe at that time. There are references to Krystyna Szwedzka, Tsarina Catherine the Great, as well as Mrs Geoffrin, engaged in the socalled "literary republic" referred to in two textbooks.

In her salon

gathered the intellectuals; literary and philosophical works were presented, and later subjected to evaluation during discussions, in which women also participated, which

${ }^{25}$ Ibidem.

${ }^{26}$ T. Małkowski, J. Rześniowiecki, Podróże w czasie. Historia I. Podręcznik do gimnazjum, Gdańsk 2009, p. 191.

${ }^{27}$ L. Moryksewicz, M. Pacholska, W. Zdziabek, Poznajemy przeszłość. Historia 1. Gimnazjum, Toruń 2009, p. 175. 
was a novelty at the time. The voice of the salons (the so-called public opinion) determined the value of any given idea or work. ${ }^{28}$

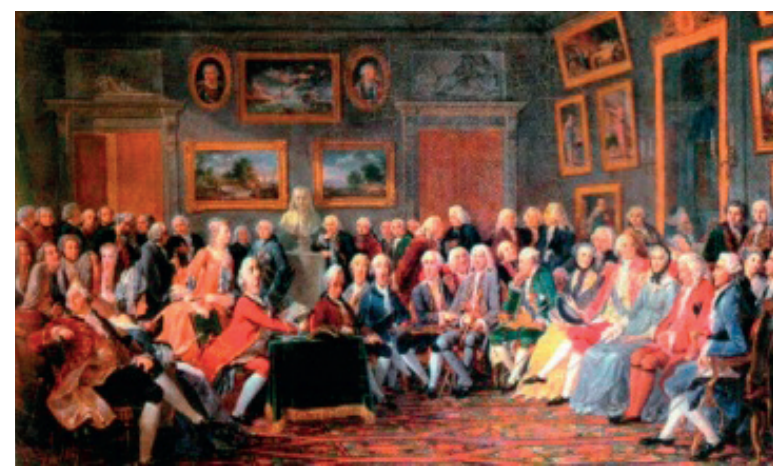

Fig. 7. „The Salon of Madame Geoffrin (...) in Paris. In such salons, led by intelligent and elegant women, philosophers met willingly. A bust of Voltaire occupies the central wall, and Diderot and Rousseau are among those present. Image from the early $19^{\text {th }}$ century" 29

The participation of these female rulers in the intellectual life of modern Europe is mentioned in two textbooks, and represented with a visual material concerning Christina of Sweden:

Fig. 8. „Descartes at the court of the Swedish queen Christina, a fragment of a painting by Pierre Louis Dumesnil, 18th century (...) Descartes' knowledge was widely appreciated in Europe. Among other places, he was at the court of the Swedish queen Christina, leading philosophical dialogues with her"30

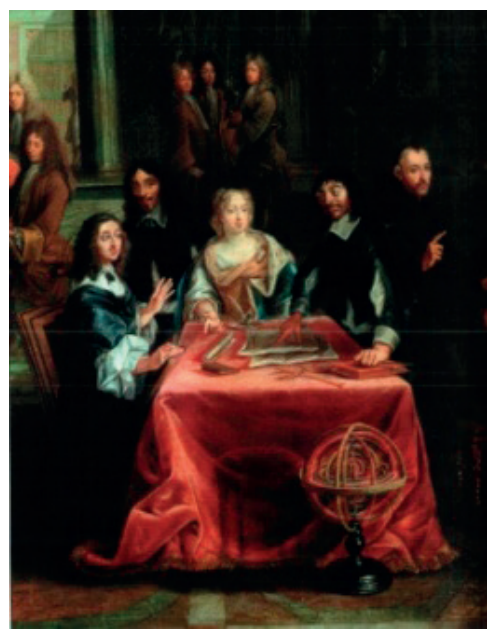

Information about the second ruler, Catherine, who actively participated in the eighteenth-century European intellectual life, can be found in three textbooks. The most comprehensive, though also the most unflattering, characteristic is included in the textbook "History. Modern times. Handbook for lower secondary school. Class II":

${ }^{28}$ G. Kucharczyk, P. Milcarek, M. Robak, Przez tysiąclecia i wieki. Historia. Gimnazjum. Podręcznik. Klasa 2, Warszawa 2010, p. 276.

29 T. Małkowski, J. Rześniowiecki, Podróże w czasie, p. 10.

${ }^{30}$ J. Ustrzycki, Historia 2. Podręcznik dla gimnazjum, Gdynia 2010, p. 140; G. Kucharczyk, P. Milcarek, M. Robak, Przez tysiaclecia i wieki, p. 178. 
Katarzyna II (...) Ruthless and cunning (...) she was perceived in the 'enlighted' circles of Europe a the gentle ruler, caring for the good of her subjects, deceiving even such eminent thinkers as Voltaire and Diderot. She corresponded with philosophers who sowed her with praise. In fact, she suppressed all attempts to revolt and shed servitude $(\ldots)^{31}$.

\section{Two Centuries of Skłodowska-Curie (from the Modern Age to the present day)}

In history textbooks the nineteenth century starts with the Napoleonic Wars, and ends in 1918. In school textbook narrative this is the era of countless discoveries and inventions by the scores of highly educated men, gifted with true genius, and only one woman: Marie Skłodowska-Curie.

The story of Izabela Czartoryska - a patron and guardian of Polish national culture - should be considered episodic. She is laconically described as the founder of

(...) the Temple of Remembrance, also known as the Temple of the Sibyl. (...) In this building, the founder collected family and national souvenirs. She was guided by the message that was posted above the entrance to the temple: The Past of the Future. ${ }^{32}$

Against this background, the narrative dedicated to Skłodowska-Curie looks impressive.

Organising the textbook historical narrative dedicated to the Polish scientist we divided it into five categories, taking into account the methods used

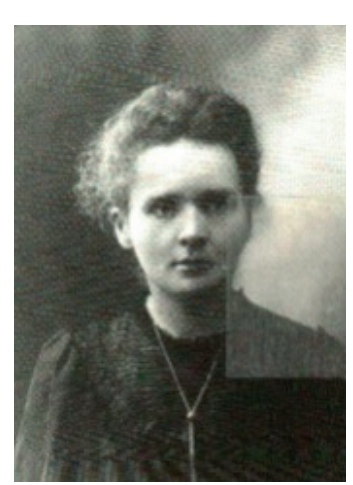
to depict her:

- portraits of the scientist, accompanied by her biography

Fig. 9. „Maria Skłodowska-Curie (1867-1934),

physicist and chemist, photograph from around $1898^{\prime \prime 33}$

${ }^{31}$ J. Chachaj, J. Drob, Historia. Czasy nowożytne. Podręcznik dla gimnazjum. Klasa II, Warszawa 2010, p. 92.

${ }^{32}$ M. Jadczak, M. Meissner-Smoła, S. Zając, Poznajemy przeszłość. Historia 2. Podręcznik dla gimnazjum, Toruń 2010, p. 228; J. Sikorska-Kulesza, W kalejdoskopie dziejów. Wiek XIX. Podręcznik do historii. Gimnazjum. Klasa 3, Warszawa 2011, p. 22, 24.

${ }^{33}$ Z. Bentkowska-Sztonyk, E. Wach, Człowiek i jego cywilizacja. Podręcznik do klasy 3, Wrocław 2011, p. 209. 


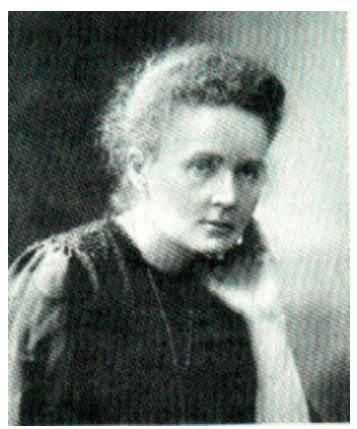

Fig. 10. „Maria Sklodowska-Curie. 1876-1934r. She was a physicist and chemist, co-creator of the science of radioactivity. She spent her childhood and early youth in Poland. In 1891, she went to Paris to study. As the first woman in history, she passed her entrance exams at the Faculty of Physics and Chemistry at the Sorbonne in Paris. After graduation, she worked in the laboratory. In 1894, she met her future husband, Pierre Curie, whom she married one year later. They conducted joint research, culminating in the discovery in 1898 of two radioactive elements - polonium and radium. In 1903, together with her husband and Becquerel, she received the Nobel Prize in physics for radioactivity research. In 1911, she was awarded the Nobel Prize for the second time - this time in the field of chemistry for the separation of pure radium. In 1914, she founded the Radium Institute in Paris, and in 1932 - in Warsaw. As the first woman she became a professor of the Sorbonne. She died of leukemia caused most probably by taking too high a dose of radiation" 34

- portraits of the scientist in her laboratory

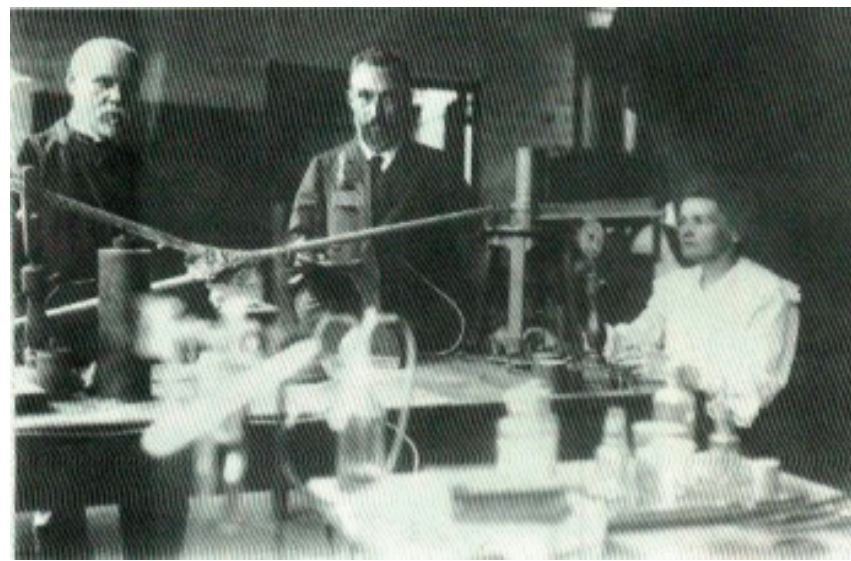

Fig. 11. „Maria Curie-Skłodowska with her husband Piotr in the chemical laboratory" 35

${ }^{34}$ S. Roszak, A. Łaszkiewicz, Śladami przeszłości. Podręcznik do historii dla klasy trzeciej gimnazjum, Warszawa 2011, p. 192.

${ }^{35}$ J. Sikorska-Kulesza, W kalejdoskopie dziejów. Wiek XIX, p. 2014. 


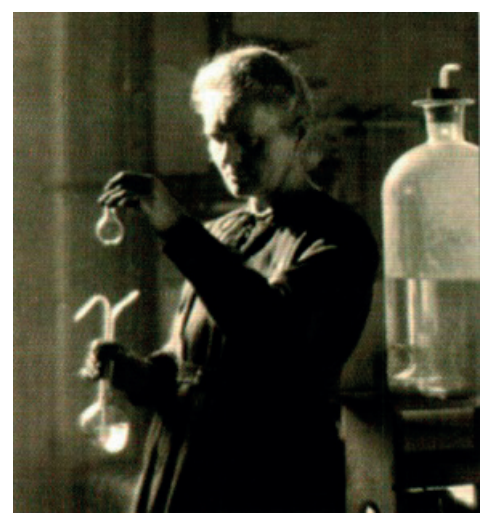

Fig. 12. „Maria Skłodowska-Curie in her laboratory in Paris, photography from the beginning of XX century"36

- the scientist's breakthrough discoveries and Nobel Prize winning (all textbooks present the topic of her scientific work together with her husband, Piotr Curie).

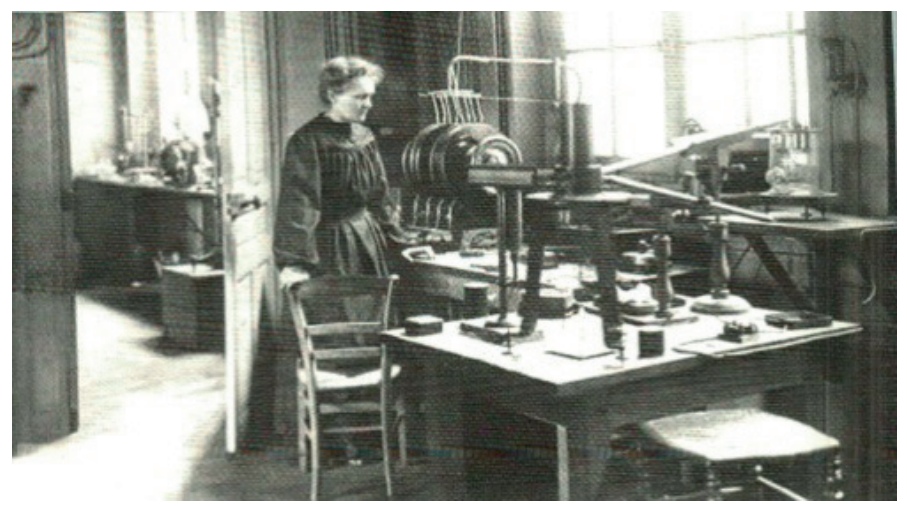

Fig. 13. „Maria Skłodowska-Curie (1867-1934) gained fame in the world as a researcher of radioactivity and a discoverer of two new elements - radium and polonium. She was the first woman to win the Nobel Prize. She received it in physics in 1903 (together with her husband Pierre Curie and Henry Bequerel). In 1911, she was honored for the second time with the Nobel Prize in Chemistry. Thanks to the discovery of radioactivity, science, medicine and industry have gained a great momentum until today. Explain why the scholar called the discovered element polonium. Check who was the second-ever Nobel laureate in chemistry" ${ }^{\prime \prime}$

${ }^{36}$ Z. Bentkowska-Sztonyk, E. Wach, Człowiek i jego cywilizacja, p. 126; J. Sikorska-Kulesza, W kalejdoskopie dziejów. Wiek XIX, p. 214-215.

37 E. Chorąży, K. Dyba, S. Zając, Poznajemy przeszłość. Historia 3. Gimnazjum, Toruń 2011, p. 120. 
In 1898 Maria Skłodowska-Curie (...) - a Polish scholar - and her husband, a Frenchman - Piotr Curie - discovered two radioactive elements: polonium and radium. For their achievement they were awarded the Nobel Prize (twice in case of Maria Skłodowska-Curie). ${ }^{38}$

A major contribution to the development of chemistry and physics was made by Maria Skłodowska-Curie, who together with her husband, Piotr Curie, discovered new elements: polonium and radium. ${ }^{39}$

In research on radioactivity, a huge contribution was made by Maria SkłodowskaCurie and her husband, Piotr Curie. They discovered two radioactive elements - polonium and radium..$^{40}$

The work on radiation was also carried out by a Pole, Maria Skłodowska-Curie (...). Together with her husband, she discovered radioactive elements of polonium and radium and introduced the concept of radioactivity into science. ${ }^{41}$

Polish scholar Mary Skłodowska-Curie (...) from 1891 studied and then worked in Paris. She received the Nobel Prize twice: in 1903 with her husband Piotr Curie, in the field of physics (for research on natural radioactivity and the discovery of radioactive elements - radium and polonium) and in 1911 in the field of chemistry (for further work on the properties of radioactive elements). Her research on radioactivity has greatly contributed to the development of new methods for the diagnosis and treatment of many diseases. ${ }^{42}$

- Scientist placed in one line with the best scientists in the world in the context of the development of science and technology, discoveries and inventions at the turn of the $19^{\text {th }}$ and $20^{\text {th }}$ centuries:

Groundbreaking discoveries have also been made in the field of physics and chemistry. (...) A new field of science dealing with radioactivity has been created. This phenomenon was discovered in 1896 by a French scholar Antoine Henri Becquerel, and research in this field was conducted by a French-Polish couple - Pierre Curie and Maria Skłodowska-Curie. ${ }^{43}$

The Frenchman Henri Antoine Becquerel described the phenomenon of radioactivity, and in 1898, a Pole, Maria Skłodowska-Curie, together with her husband, Frenchman Piotr Curie, discovered two radioactive elements, polonium and radium. ${ }^{44}$

\footnotetext{
${ }^{38}$ Z. Bentkowska-Sztonyk, E. Wach, Człowiek i jego cywilizacja, p. 126.

${ }^{39}$ Ibidem, p. 207.

${ }^{40} \mathrm{~J}$. Ustrzycki, Historia 1. Podręcznik dla gimnazjum, p. 97.

${ }^{41}$ T. Małkowski, J. Rześniowiecki, Podróże w czasie, p. 171.

${ }^{42}$ I. Kąkolewski, A. Plumińska-Mieloch, Bliżej historii. Gimnazjum. Podręcznik. Klasa 3, Warszawa 2009, p. 136

${ }^{43}$ Ibidem, p. 191.

${ }^{44}$ J. Chachaj, J. Drop, Historia. Czasy nowożytne, p. 55.
} 
In the second half of the nineteenth century, the discoveries of scholars were quickly used in medicine and industry. Ludwik Pasteur, the creator of microbiology, invented the rabies vaccine and his work contributed to the progress of hygiene. Wilhelm Roentgen discovered X-rays, which were used in X-ray machines. Maria Skłodowska-Curie introduced the concept of radioactivity into science. Charles Darwin announced the theory of evolution, which caused a scientific scandal. ${ }^{45}$

\section{- the scientist as a symbol of the women's struggle for equal rights}

In the first half of the nineteenth century, women did not have electoral rights. They also were not allowed to study or perform many professions (e.g. a journalist). If they worked, they earned less than men. Wife's salary and savings belonged to her husband (so he took them in the event of a divorce). This unevenness of the position caused the opposition of many women. They fought for emancipation, i.e. equality with men. The first female organizations were founded at the end of the 18th century in the United States and France. In the second half of the $19^{\text {th }}$ century, associations were founded in various European countries that demanded equality between both genders. Women were quickest to break the monopoly of men in education. In 1863, women were allowed to study in France, and in 1897 - in Galicia. However, the first woman became a lecturer at the Sorbonne in Paris only in 1906. It was Maria Skłodowska-Curie. The struggle of emancipationists for electoral rights turned out to be more difficult. Men thought that the participation of women in politics would violate the delicate "foundations of their nature". One of the German writers protested against this view. In England, women fighting for electoral rights were called suffragettes (...). They started their campaign at the beginning of the 20th century. To draw attention of the public, they interrupted the meetings of men, chained to fences and knocked out shop windows. The suffragette's actions did not change the situation. It was not England, where women were the first to get active and passive electoral rights, but its colony New Zealand (1893). In Europe, the first country to grant women their electoral rights was Finland (1906). In the majority of European countries however women received the right to vote only after the First World War (e.g. in Germany and Poland in 1918). ${ }^{46}$

At the end of the eighteenth century, during the war for independence of the United States and the French Revolution, women began to claim their rights. It was a completely new and surprising phenomenon for men. Until now, most women did not have education, and their role in society was limited to domestic work and raising children. However, along with economic changes, progressing democratization of public life and striving for equality of various social groups, women began to fight for their rights. Supporters of emancipation, striving for equality and liberation from the dependence of men, were called emancipationists. Their main postulates included access to higher education, changes in family law, economic equality and obtaining electoral rights. The first freedom gained by women was the access to universities - universities were initially opened for women in France, Switzerland, the Scandinavian countries and the USA. The first woman with the professor title was Maria Skłodowska-Curie, who obtained it at the Sorbonne in Paris in 1906. American women were the leaders in the emancipation movement. The most women who were the first in the world to be-

\footnotetext{
${ }^{45}$ T. Małkowski, J. Rześniowiecki, Podróże w czasie, p. 177.

${ }^{46}$ J. Chachaj, J. Drob, Historia. Czasy nowożytne, p. 175-176.
} 
come doctors, pastors and lawyers came from the United States. The most difficult for supporters of equal rights turned out to be electoral rights. Suffragettes fought for it. The name of the traffic comes from the English word ,suffrage', which meant , the right to vote'. Despite the resistance of the conservative part of society, their actions were successful. The women's electoral rights were earned the earliest in the American state of Wyoming in 1869, and then also in the British dominions - New Zealand and Australia. In Europe, Finnish women earned equality the fastest. Polish women received the right to vote together with the establishment of an independent state in $1918 .{ }^{47}$

In the textbooks for the first year of secondary school, Marie SkłodowskaCurie appears three times: once among the Polish scientists (exclusively men) bearing witness to the status of Polish universities during the interwar period; a second time due to the opening of the Radium Institute in Warsaw in 1932; and finally on the inner cover of one of the textbooks. ${ }^{48}$

\section{Women's Era?}

In the age of universal access to education, including universities, after women went to work, remodelling family life, fitting together more and more different roles, in the history textbooks their participation in the intellectual life of Poland, Europe, or worldwide is almost unnoticeable in history textbooks. It is shocking, considering the number and diversity of careers of the prominent figures of women of science, as well as wealth and easy access to sources. In textbooks for Year One of secondary school, besides the already mentioned Marie Skłodowska-Curie, among the female scientists there appear: two academics in the role of politicians, three academics, as the authoresses of sourcebooks for students and Walentina Tiereszkowa - the first woman astronaut. ${ }^{49}$ Valentina Tereshkova found her way into one of eight textbooks as the first woman in space. We would not, however, learn anything about her scientific career from that textbook.

Among the female politicians coming from the world of science, in the school textbooks mentioned are Professor of Economics Danuta Hubner, in her role as a negotiator for the Polish accession to the EU from 1998, ${ }^{50}$

47 S. Roszak, A. Łaszkiewicz, Śladami przeszłości, p. 202.

48 Z.T. Kozłowska, I. Unger, S. Zając, Poznajemy przeszłość. Szkoła ponadgimnazjalna, zakres podstawowy, Toruń 2012, p. 99; A. Brzozowski, G. Szczepański, Ku wspótczesności. Dzieje najnowsze 1918-2006. Podręcznik do historii dla klasy I szkoty ponadgimnazjalnej. Zakres podstawowy, Warszawa 2012, p. 53; J. Ustrzycki, Ciekawi świata. Historia podręcznik zakres podstawowy, Warszawa 2012.

${ }^{49}$ A. Brzozowski, G. Szczepański, Ku wspótczesności. Dzieje najnowsze 1918-2006, p. 186.

${ }^{50}$ B. Burda et al., Część I. Historia. Historia najnowsza, podręcznik dla szkót ponadgimnazjalnych, zakres podstawowy, Gdańsk 2013, p. 157; R. Dolecki, K. Gutowski, J. Smoleński, Po prostu historia, Warszawa 2012. 
and Hanna Suchocka - a assistant law professor, in her role as the Polish Prime Minister. ${ }^{51}$ None of the textbooks mentions the fact that those women achieved an academic career; we only learn that Hanna Suchocka graduated in Law.

Among the three authoresses of sourcebooks are: Hanna Świda-Ziemba - Professor of Sociology, ${ }^{52}$ connected to the University of Warsaw, Hanna Arendt - philosopher and publicist, Professor at the University of Chicago, and the New School for Social Research in New York ${ }^{53}$ and Krystyna Kersten Polish historian, Professor at the Historical Institute of the Polish Academy of Sciences. ${ }^{54}$

In the textbook, Hanna Arendt is advertised as the authoress of "one of the most important analyses regarding the origins of totalitarian systems (...) in her book The Origins of Totalitarianism (with a passage from the book, accompanied by the authoresses's portrait)". Krystyna Kersten is advertised with a slogan, "The era in historians' reviews", and announced as an authoress of the book The Establishment of the Communist Rule in Poland, 1943-1948. A quote from the book is accompanied by Kersten's portrait photo. Hanna Świda-Ziemba is advertised as a sociologist and the authoress of the book A man internally enslaved (Człowiek wewnętrznie zniewolony).

\section{Conclusion}

The starting point for our project was a conviction about an almost total absence of women in school historical narrative. Our research showed that this is so, even though there is no shortage of historiography about women..$^{55}$ Beginning our study of school historical narrative in view of the (non)presence of women's history, we have made two hypotheses.

The first concerned the place and role of school historical education, in particular history textbooks in shaping the cultural competences of students and pupils. Central and political management of education causes that textbooks - using the terminology of Pierre Bourdieu - are the effect and an im-

${ }^{51}$ Ibidem, p. 298, 343; B. Burda et al., Część I. Historia. Historia najnowsza, p. 153; D. Stola, Historia wiek XX. Podręcznik, Warszawa 2018, p. 236, 238; S. Zając, Teraz historia. Podręcznik dla szkoły ponadgimnazjalnej. Zakres podstawowy, Torun 2012, p. 265; A. Brzozowski, G. Szczepański, Ku wspótczesności. Dzieje najnowsze 1918-2006, p. 282, 270.

${ }^{52}$ D. Stola, Historia wiek XX, p. 158.

${ }^{53}$ S. Roszak, J. Kłaczkow, Poznać przeszłość. Wiek 20 (XX). Podręcznik do historii dla szkót ponadgimnazjalnych. Zakres podstawowy, Warszawa 2016, p. 64.

${ }^{54}$ Ibidem, p. 268.

${ }^{55}$ For more, see: I. Chmura-Rutkowska, E. Głowacka-Sobiech, I. Skórzyńska, Niegodne historii? p. 24-38. 
portant and useful, taking into account the mass and range of possible interactions, tool of symbolic violence, defined by the author as:

every power that manages to impose meaning, and impose it as legitimate, hiding the systems of forces that underlie its power, adds to its systems of power its own power, that is, purely symbolic power. ${ }^{56}$

When we go down to the level of school and classroom, the concept of a hidden program turns out to be extremely difficult. In Philip Jackson's classical approach, the "hidden program" is all the "unplanned" effects and consequences of going to school. ${ }^{57}$ However, many authors and researchers have pointed to the fact that we learn at school all the relevant things to our whole life not only "beside" or "outside" the official program. The hidden aspects of the official curriculum itself are equally important, and, as E.W. Eisner ${ }^{58}$ points out, various types of "gaps", meaning the content omitted in school education (whole fields of knowledge, information, research results and experience), as well as intellectual processes, which students are not subjected to (alternative, critical, creative thinking). These shortcomings E.W. Eisner called the null curriculum. Shortages, usually unnoticed by students and teachers, are not neutral from the point of view of the individual's development. As noted by D. Gordon, 59 "gaps" in the form of ignorance or limited knowledge, lack of competence, experience, mental barriers, etc. result in the selection and elimination of various options of thinking and acting of the individual. As Zbigniew Kwieciński remarks, the "null curriculum" in Poland in relation to history is referred to as "white spots". ${ }^{60}$ "But these 'spots' can not be seen. On the contrary, the gaps are not generally shown to teachers, they are hidden from them". ${ }^{61}$

The second hypothesis concerns the evaluation of the value of a school's historical narrative due to its not only cognitive character, but also its identity and its connections, sometimes very large and very unaware, with discourses of memory, and thus not only with historiography. Although the textbook is a medium that potentially transmits the current historical knowledge to the school circulation of this knowledge, at the same time this process is subjected to two strictly connected rigors: 'knowledge and cognition' and 'memory and

${ }^{56}$ P. Bourdieu, J.C. Passeron, Reprodukcja, Warszawa 2006.

57 P.W. Jackson, Life in the Classrooms, New York 1968.

58 E.W. Eisner, The Educational Imagination, New York 1979.

${ }^{59}$ D. Gordon, Hidden curriculum, [in:] International Encyclopaedia of the Sociology of Education, Ed. L.J. Saha, Oxford 1997.

${ }^{60}$ Z. Kwieciński, Pedagogiczne zero. Zastosowania problemowe, epistemiczne i magiczne, Nauka, 2004, 2.

${ }^{61}$ For more, see: I. Chmura-Rutkowska, E. Głowacka-Sobiech, I. Skórzyńska, Niegodne historii? p. 13-19. 
identity'. These rigors place the history textbook at the intersection of two essential functions fulfilled by it in culture and social life, namely cognitive (a content carrier of the current state of historical knowledge) and identity (the source of transmission/shaping of collective memory). ${ }^{62}$ In the first case, when the textbook is a carrier of content about the current state of historical knowledge, the authors of the textbooks appear as those who are primarily responsible for the real, that is, currently methodologically/methodically correct view of history represented by the textbook narrative. In the second case, when the textbook is both an effect of the historical policy of the state and a tool for shaping collective memory, there are curricula behind it, minimum requried knowledge and skills, and after 1999 - a general educaton standard, that expresses the intentions of the state about what (content), how (with what methods) and for what purpose should the student finish the successive stages of compulsory historical education in a Polish school. Taking into account the cognitive and identity shaping function of the history textbook, we can say in a simplified way that the second of the rigors determines the first one. This means that the history book is a product of the culture of history, and thus of such a culture/cultures where the past is subject to greater or lesser valuation, and as such is not only the object of cognition, but also a memory carrier and a source of collective and/or individual identity. ${ }^{33}$ Such meaning of history textbooks is proposed by Barbara Szacka - as a medium of collective memory. ${ }^{64}$ Henri Moniot also draws attention to this dimension of the history textbook, when he writes that it is ",an effect, a sign, a vehicle or an instrument of shaping values, opinions, ideologies", ${ }^{65}$ a substitute for experiencing the past in its absence "here and now", a response to social fears what makes it a tool of current ideologies, a morality play shaping students' attitudes by showing good and bad deeds. Yet another author, Keith Crawford, ${ }^{66}$ writes explicitly that a textbook is a cultural artifact whose contents, both at the stage of their construction and functioning in the school circuit, are confronted with ideology, politics and values at various levels of power, influence and status. ${ }^{67}$

${ }^{62}$ M. Bieniek, Hasło: Podręcznik szkolny historii, [in:] Wspótczesna dydaktyka historii. Zarys encyklopedyczny, Ed. J. Maternicki, Warszawa 2004; D. Konieczka-Śliwińska, Retoryka we wspótczesnych szkolnych podręcznikach historii, Poznań 2001.

${ }^{63}$ P. Nora, Mémoire collective, [in:] Faire de l'histoire, Eds. Le Goff, P. Nora, Paris 1974; A. Szpociński, Miejsca pamięci (lieux de mémoire), «Sites of Memory», Teksty Drugie, 2008, 4, p. 11-20.

${ }^{64}$ B. Szacka, Trzy sfery pamięci zbiorowej - historia, media i "ludzkie gadanie", Znak, 2012, 683.

${ }^{65}$ H. Moniot, Didactique de l'histoire, Paris 1993, p. 29; G. Marin, Pamięć bez historii, historia bez pamięci. Nowe rumuńskie podręczniki do nauczania historii - nostalgia za Ceaușescu, [in:] Inscenizacje pamięci, Eds. I. Skórzyńska, Ch. Lavrence, C. Pèpin, Poznań 2007, p. 198.

${ }^{66} \mathrm{~K}$. Crawford, The Role and Purpose of Textbooks, International Journal of Historical Learning, Teaching and Research, 2003, 3.

${ }^{67}$ For more, see: I. Chmura-Rutkowska, E. Głowacka-Sobiech, I. Skórzyńska, Niegodne historii? p. 20-41. 
It can be observed that although there are no women scientists in history textbooks (Skłodowska is the absolute exception), they appear as representatives of the world of art and culture, at least in relation to modernity and the newest times. In turn, even if women scientists achieve a very high position in politics or media, there is no reference in the textbooks that they owe this position to the university intellectual formation, which they co-formed and/ or co-shaped and from which they derive knowledge and skills guaranteeing their success on others fields of activity. It is worth adding at the end that the stereotypical belief about the "weakness" of women in science has been funded in the past on the stereotype of biological determinism (we are not sure whether this stereotype does not work to this day), proclaiming the lack of psycho-physical predispositions of women to pursuit scientific work. Another determinant was/still is the belief about the cultural conditions (predispositions and deficits) of the absence of women among prominent scientists occupying prestigious positions at universities and research institutions. These two determinants are also the effect of the school null curriculum, which - in the light of our textbook analysis - effectively persuades that up to the nineteenth century women were destined to take care of the home and children, educated only by mothers, deprived of the rights and functioning as victims, and never as beneficiaries of social systems, in which their role was limited only to acting in the private sphere.

It is true that the textbooks admit that at the threshold of modernity women began to count as the causative agents of history, but but alluding is how they benefited from this change. Their emancipation is recorded in the sphere of customs, including family and fashion, work and earnings, culture and politics, but never science. Maria Skłodowska-Curie remains the only symbol of a woman-academic in the school textbook narrative. This is a source of pride, but at the same time an insufficient source of identification for girls and women who are learning to enter the world of science, who are well-suited to the role of organizers of academic life, but are not necessarily visible in the scientific mainstream. Data from the Polish Central Statistical Office for 2014 show that doctoral theses are written and defended by almost as many women as men. However, only $23 \%$ of female doctors receive the title of professor. ${ }^{68}$ This problem, called the Leaky Pipeline, occurs all over the world, although in a slightly different quantitative dimension. ${ }^{69}$

Post Scriptum. Changing the school system in Poland in 2017 also changed the place, role and content of school education in history. The content and

${ }^{68}$ GUS, Szkoty wyższe i ich finanse w 2014 roku, Warszawa 2015.

${ }^{69}$ UNESCO, Cracking the code: Girls' and women's education in science, technology, engineering and mathematics, Paris 2017. http://unesdoc.unesco.org/images/0025/002534/253479e.pdf. [01.02.2019]; C. Hill, Ch. Corbett, A.S. Rose, Why So Few? Women in Science. 
aims of this education refers again to the pre-modern paradigm. Despite studies, recommendations and debates, school history remains military, national, and maskulinized. For the academic careers of Polish girls it is not good news because they do not have again their own history.

\section{BIBLIOGRAPHY}

Bieniek M., Hasło: Podręcznik szkolny historii, [in:] Wspótczesna dydaktyka historii. Zarys encyklopedyczny, Ed. J. Maternicki, Warszawa 2004.

Bobako M., Powrót kobiet do historii - niedokończony projekt? Krytyka Polityczna, 2005, 7-8.

Bourdieu P., Passeron J.C., Reprodukcja, Warszawa 2006.

Chmura-Rutkowska I., Głowacka-Sobiech E., Skórzyńska I., Niegodne historii? O nieobecności $i$ stereotypowych wizerunkach kobiet w świetle podręcznikowej narracji historycznej w gimnazjum, Poznań 2015.

Crawford K., The Role and Purpose of Textbooks, International Journal of Historical Learning, Teaching and Research, 2003, 3.

Dzierzgowska A., Laskowski P., Opinia zespołu Społecznego Monitora Edukacji o projekcie podstawy programowej z historii dla liceum ogólnoksztatcacego i technikum. Warszawa 2017. https://www.monitor.edu.pl/analizy/opinia-o-projekcie-podstawy-programowej-z-historii-dla-liceum-ogolnoksztalcacego-i-technikum.html [01.02.2019].

Eisner E.W., The Educational Imagination, New York 1979.

European Commission, SHE FIGURES 2015, Gender in Research and Innovation, Brussels 2015. https://ec.europa.eu/research/swafs/pdf/pub_gender_equality/she_figures_ 2015-final.pdf. [01.02.2019].

Fandrejewska-Tomczyk A., Raport L'Oréal Polska Piękne umysty - rola kobiet w świecie nauki, Warszawa 2016. http://lorealdlakobietinauki.pl/wp-content/uploads/2016/ 05/16-04-26_Raport_Piekne_umysly-rola_kobiet_w_swiecie_nauki.pdf. [01.02.2019].

Felski R., Fin de siecle, fin de sexe: transeksualizm i śmierć historii, [in:] Pamięć, etyka i historia. Anglo-amerykańska teoria historiografii lat dziewiećdziesiatych (Antologia przekładów), Ed. E. Domańska, Poznań 2002.

Głowacka-Sobiech E., Michalski M., Napierała A., Skórzyńska I., Historia - raport przedmiotowy, [in:] Gender w podręcznikach. Projekt badawczy. Raport, t. III - Raporty przedmiotowe i rekomendacje, Eds. I. Chmura-Rutkowska, M. Duda, M. Mazurek, A. Sołtysiak-Łuczak, Warszawa 2016.

Gordon D., Hidden curriculum, [in:] International Encyclopaedia of the Sociology of Education, Ed. L.J. Saha, Oxford 1997.

GUS, Szkoły wyższe i ich finanse w 2014 roku, Warszawa 2015.

Hill C., Corbett Ch., Rose A.S., Why so few? Women in Science, Technology, Engineering, and Mathematics, AAUW, Washington 2010. https://www.aauw.org/files/2013/02/ Why-So-Few-Women-in-Science-Technology-Engineering-and-Mathematics.pdf. [01.02.2019].

Jackson P.W., Life in the Classrooms, New York 1968.

Karkowska M., Socjalizacja rodzajowa dziewczat i chłopców a ukryty program edukacji szkolnej, [in:] Role ptciowe. Kultura i edukacja, Ed. M. Chomczyńska-Rubacha, Łódź 2006.

Kekelis L., Joyce J., How Role Models Can Make the Difference for Girls, The Journal of Expanded Learning, Spring 2014. 
Konieczka-Śliwińska D., Retoryka we wspótczesnych szkolnych podręcznikach historii, Poznań 2001.

Kopciewicz L., Rodzaj i edukacja. Studium fenomenograficzne z zastosowaniem teorii społecznej Pierre'a Bourdieu, Wrocław 2007.

Kwieciński Z., Pedagogiczne zero. Zastosowania problemowe, epistemiczne i magiczne, Nauka, 2004, 2.

Marin G., Pamięć bez historii, historia bez pamięci. Nowe rumuńskie podręczniki do nauczania historii - nostalgia za Ceaușescu, [in:] Inscenizacje pamięci, Eds. I. Skórzyńska, Ch. Lavrence, C. Pèpin, Poznań 2007.

Meighan R., Socjologia edukacji, Torun 1993.

Microsoft, How role models are changing the face of STEM in Europe, 2017. https://news. microsoft.com/europe/features/girls-in-stem-the-importance-of-role-models/. [01.02.2019].

Moniot H., Didactique de l'histoire, Paris 1993.

Nora P., Mémoire collective, [in:] Faire de l'histoire, Eds. Le Goff, P. Nora, Paris 1974.

Swaby R., Upór i przekora. 52 kobiety, które odmienity naukę i świat, Warszawa 2017.

Szacka B., Trzy sfery pamięci zbiorowej - historia, media i "ludzkie gadanie", Znak, 2012, 683.

Szpociński A., Miejsca pamięci (lieux de mémoire), «Sites of Memory», Teksty Drugie, 2008, 4.

UNESCO, Girls into Science: A training Module, Paris 2007. file:/ / C:/Users/Krystyna/Desktop/Iwona/Girls\%20into\%20Science\%20UNESCO.pdf

UNESCO, Cracking the code: Girls' and women's education in science, technology, engineering and mathematics, Paris 2017. http://unesdoc.unesco.org/images/0025/002534/253479e. pdf. [01.02.2019].

\section{List of school textbooks for history analyzed and cited in the text}

Bentkowska-Sztonyk Z., Wach E., Człowiek i jego cywilizacja. Podręcznik do klasy 3, Wrocław 2011.

Brzozowski A., Szczepański G., Ku wspótczesności. Dzieje najnowsze 1918-2006. Podręcznik do historii dla klasy I szkoty ponadgimnazjalnej. Zakres podstawowy, Warszawa 2012.

Burda B., Halczak B., Józefiak R.M., Roszak A., Szymczak M., Część I. Historia. Historia najnowsza, podręcznik dla szkót ponadgimnazjalnych, zakres podstawowy, Gdańsk 2013.

Chachaj J., Drob J., Historia. Czasy nowożytne. Podręcznik dla gimnazjum. Klasa II, Warszawa 2010.

Chorąży E., Dyba K., Zając S., Poznajemy przeszłość. Historia 3. Gimnazjum, Toruń 2011.

Dolecki R., Gutowski K., Smoleński J., Po prostu historia, Warszawa 2012.

Jadczak M., Meissner-Smoła M., Zając S., Poznajemy przeszłość. Historia 2. Podręcznik dla gimnazjum, Torun 2010.

Kąkolewski I., Plumińska-Mieloch A., Bliżej historii. Gimnazjum. Podręcznik. Klasa 3, Warszawa 2009.

Kozłowska Z.T., Unger I., Zając S., Poznajemy przeszłość. Szkoła ponadgimnazjalna, zakres podstawowy, Torun 2012.

Kucharczyk G., Milcarek P., Robak M., Przez tysiaclecia i wieki. Historia. Gimnazjum. Podręcznik. Klasa 2, Warszawa 2010.

Kulesza R., Ciara S., Klasa 1. W kalejdoskopie dziejów. Podręcznik do historii, Warszawa 2009.

Małkowski T., Rześniowiecki J., Podróże w czasie. Historia I. Podręcznik do gimnazjum, Gdańsk 2009.

Moryksewicz L., Pacholska M., Zdziabek W., Poznajemy przeszłość. Historia 1. Gimnazjum, Toruń 2009. 
Roszak S., Śladami przeszłości. Podręcznik do historii dla klasy drugiej gimnazjum, Warszawa 2010.

Roszak S., Kłaczkow J., Poznać przeszłość. Wiek 20 (XX). Podręcznik do historii dla szkót ponadgimnazjalnych. Zakres podstawowy, Warszawa 2016.

Roszak S., Łaszkiewicz A., Śladami przeszłości, Podręcznik do historii dla klasy trzeciej gimnazjum, Warszawa 2011.

Sikorska-Kulesza J., W kalejdoskopie dziejów. Wiek XIX. Podręcznik do historii. Gimnazjum. Klasa 3, Warszawa 2011.

Stola D., Historia wiek XX. Podręcznik, Warszawa 2018.

Trzcionkowski L., Wojciechowski L., Historia. Starożytność, średniowiecze. Podręcznik dla gimnazjum. Klasa I, Warszawa 2009.

Ustrzycki J., Historia 1. Podręcznik dla gimnazjum, Gdynia 2009.

Ustrzycki J., Ciekawi świata. Historia podręcznik zakres podstawowy, Warszawa 2012.

Zając S., Teraz historia. Podręcznik dla szkoły ponadgimnazjalnej. Zakres podstawowy, Torun 2012.

\section{Curricula}

MEN, 2017, Podstawa programowa kształcenia ogólnego dla szkoły podstawowej. https:// podstawaprogramowa.pl/Szkola-podstawowa-IV-VIII/ [30.11.2019].

MEN, 2018, Podstawa programowa kształcenia ogólnego dla czteroletniego liceum ogólnokształcącego i pięcioletniego technikum. https://podstawaprogramowa.pl/Liceum-technikum/Historia [30.11.2019].

Rozporządzenie Ministra Edukacji Narodowej z 14 lutego 2017 r. w sprawie podstawy programowej wychowania przedszkolnego oraz podstawy programowej kształcenia ogólnego dla szkoły podstawowej, w tym dla uczniów z niepełnosprawnością intelektualną w stopniu umiarkowanym lub znacznym, kształcenia ogólnego dla branżowej szkoły I stopnia, kształcenia ogólnego dla szkoły specjalnej przysposabiającej do pracy oraz kształcenia ogólnego dla szkoły policealnej (DzU z 2017 r.), poz. 365. http:/ / dziennikustaw.gov.pl/du/2017/365/1 [30.11.2019].

Rozporządzenie Ministra Edukacji Narodowej z 30 stycznia 2018 r. w sprawie podstawy programowej kształcenia ogólnego dla liceum ogólnokształcącego, technikum oraz branżowej szkoły II stopnia (DzU z 2018 r.), poz. 467. http://www.dziennikustaw. gov.pl/DU/2018/467 [30.11.2019]. 